\title{
COMPARATIVE ANALYSIS OF THE MECHANICAL PROPERTIES BETWEEN THE FIBER-REINFORCED COMPOSITE AND ZIRCONIUM POSTS
}

\author{
Vesna Jurukovska-Shotarovska, Biljana Kapusevska
}

Faculty of dentistry, University "St. Cyril and Methodius", Skopje, R. Macedonia

Corresponding Author: Vesna Jurukovska Shotarovska MD, PhD, Faculty of dentistry, University St. Cyril and Methodius, Majka Tereza, PO BOX 17, 1000 Skopje, R. Macedonia; Tel: ++ 389 (0)2 32990 00,

Fax: ++ 389 (0)2 32201 41; Url: http://www.stomfak.ukim.edu.mk/; E-mail: biljanakapusevska @ gmail.com

\begin{abstract}
Objectives: To make a comparative analysis of the mechanical properties between FRC and zirconium posts

Methods: The patients with FRC and zirconium posts were divided in two groups with three subgroups, each of them composed of 10 samples. Subgroup I with $1.2 \mathrm{~mm}$; Subgroup II with $1.35 \mathrm{~mm}$ and Subgroup III with $1.5 \mathrm{~mm}$ post diameter. The fracture force, bending and tensile strength of each group were measured with Shimadzu Universal Testing Machine.

Results: The fracture force for the first group measured in the first, second and third subgroup was $34.80900 \mathrm{~N} ; 67.15390 \mathrm{~N} ; 46.53100 \mathrm{~N}$ and for the second group, first, second and third subgroup was $34.80900 \mathrm{~N} ; 46.53100 \mathrm{~N} ; 67.15390 \mathrm{~N}$ correspondingly. The bending strength for the first group measured in the first, second and third subgroup was $401.4420 \mathrm{~N}$; $444.6425 \mathrm{~N}$; $333.6828 \mathrm{~N}$ and for the second group, first, second and third subgroup was $307.9352 \mathrm{~N} ; 289.1030 \mathrm{~N} ; 304.1649 \mathrm{~N}$ correspondingly. The tensile strength for the first group measured in the first, second and third subgroup was $5.442267 \mathrm{~N} ; 4.350545 \mathrm{~N} ; 2.943465 \mathrm{~N}$ and for the second group, first, second and third subgroup was $4.224141 \mathrm{~N} ; 3.751466 \mathrm{~N}$; $3.168756 \mathrm{~N}$ correspondingly.

Conclusions: The longest diameter of the posts significantly increases the resistance to fracture in relation to the two smaller diameters. The larger diameter, the higher values of the bending strength, as well as the lowest values of the tensile strength of the material contribute to improved mechanical properties of the fiber and zirconium posts.
\end{abstract}

Key words: FRC posts, zirconium posts, fracture, strength, bending, elasticity

\section{Introduction}

Restoration of the endodontically treated teeth is a challenge in the research of the recent decades, primarily due to the introduction of innovative materials and modern methods. Traditionally accepted method for reconstruction of the endodontically treated teeth is the use of post restoration or cast post and core restoration, which can be covered with a crown.
The cast post and core restoration must have durable and secure retention to the crown or bridge to allow proper transfer of the burden to the entire root and the surrounding supportive tissues [1]. The post and core restoration along with the rest of the tooth substance is a part of one unit which actually depicts a prepared tooth, abutment of the future prosthetic construction. [2] 
The available post and core restoration systems are usually fabricated from individually constructed metal, non-metal post and core restorations or different types of prefabricated ceramic and fiberglass posts [3].

The necessity of improved aesthetics and biocompatibility of the restorations contributed for the discovery of translucent metal-free post and core systems and their advancement [4].

Prefabricated fiberglass and zirconium post and core systems have been examined to meet the aesthetic needs of the endodontically treated incisors. The transparency of the full ceramic crowns can be successfully satisfied with the use of newly molded fiberglass and ceramic posts [2].

FRC (fiber reinforced composite) posts reinforced with composite fibers represent an alternative to many conventional materials. Compared with the processed titanium posts they lead to reduced occurrence of fracture to the tooth root. Zirconium posts used today have a high modulus of elasticity, and thus, the force from the post is directly directed to the tooth structure without stress absorption.

\subsection{Retention factors}

The necessity of retention varies depending on the type of prosthetic construction and intermaxillary relationship. There are many factors that affect the length and retention of the posts.

\subsection{Post length}

The length of the post affects the distribution of stress in the root and thus affects the resistance to fracture. When the length of the post is increased the retention capacity increases. A common recommendation is that the length of the post should be equal or longer than the length of the crown [5-8].

\subsection{Diameter of the post and the remaining dentin}

The diameter of the post and the remainning dentin also play an important role in the prevention of root fracture [9-13].

According to some studies, the increasing in the diameter of the post does not significantly affect the retentive capacities. However, this can increase the force of the post and thus increase the risk of fracture to the root $[3,14]$.

\subsection{Post design}

The design of the post affects the retention and success of the restoration. Regarding the narrowing of the post, the equidistantly positioned posts have higher retention than the compressed posts and they distribute the stress more evenly throughout their length during functioning period [15]. The higher the narrowwing is, the lower is the retention [16].

The design of the post surface can be classified as: spiked, threaded and smooth surface design. The spiked surface significantly increases the post retention compared to the smooth surface [3]. The surface design of the post can be classified as actively threaded and passively cemented post [17].

The post could either be factory ready (direct technique) or produced with the use of casting (indirect technique) in the dental laboratory. The casted metal post has been regularly applied for restoration of the endodontically treated teeth for many decades $[18,19]$.

The casted metal posts are still used today, but the procedure is expensive and requires a lot of time (usually at least two visits to the dentist) which made the fabricated posts popular among the dentists [20]

There are over 100 different factory ready posts. According to a survey of the dentists in the United States, $40 \%$ of the general dentists use factory ready posts frequently and the most popular was the spiked equidistantly positioned post [21]. The most factory ready posts are metallic, but there are several non-metallic systems. The most typical factory ready metal post is manufactured from pure steel or titanium alloys.

With the recent advantages in the ceramic technology, all ceramic crowns have become very popular. The demand for prosthodontic solutions, especially all ceramic restorations, developed new materials for fabrication of the posts.

Zirconium posts offer potential benefits in terms of aesthetics and biocompatibility [22] but they have few disadvantages. The zirconnium posts are hard, but on the other hand very fragile, with no elasticity [23]. Therefore it is important to make complete preparation for the post when using zirconium posts. Zirconium posts are not yet available in small diameters, 
which complicate the minimally invasive tooth preparation for this kind of post. If endodontic retreatment is required, a retrieval of the zirconium posts is very difficult [22].

In the early 1990 s, the processed polymerized root canal FRC (fiber-reinforced composite) posts were finally introduced on the market. One of the processed FRC (fiber-reinforced composite) posts was the C-post (Composipost) which was post made from carbon-fiber reinforced epoxy and was developed in France $[24,25]$. Very soon glass and quartz fibers were also used for the post inside the root canal. The use of the FRC (fiber-reinforced composite) in the posts of the root canal was with equal distribution, because their elastic modulus was similar to that of the dentin. When bonded in position with the resin cement mixture, it is considered that the occlusal forces are equally distributed throughout the root which results in fewer fractures of the root [25-28] and more favorable damages compared to the metal posts [29].

\section{Objectives}

Respecting the numerous literary and scientific findings that emphasize the role and mechanical properties of the different types of posts for restoration of the endodontic complex as a substructure to the prosthodontic constructions, we set the goals for this experimental investigation:

1. To compare the force of the fracture between titanium, FRC and zirconium posts

2. To examine the values of the bending force between the FRC and the zirconium posts.
3. To determine the correlation between the fracture force and the flexibility of the FRC and the zirconium posts.

4. To make comparisons between:

1) posts with the same diameter;

2) posts with different diameter;

3) what is the influence of the diameter of the post - is there a significant difference between the groups and in which groups;

4) how does the material affect the different types of posts, is there a significant difference.

\section{Material and methods}

In order to fulfil the objectives of the experimental study different types of posts were used: FRC (fiber-reinforced composite) and zirconium.

The examinations were performed at the Faculty of Dentistry in Skopje and the Faculty of Mechanical Engineering in Skopje.

For the realization of the established goal we used:

FRC and zirconium posts divided into two groups with three subgroups, each of them composed of 10 samples. Subgroup I with post diameter of $1.2 \mathrm{~mm}$; Subgroup II with post diameter of $1.35 \mathrm{~mm}$ and Subgroup III with post diameter of $1.5 \mathrm{~mm}$.

I - Group: FRC posts - "Nordin" - Switzerland (Fig. 1)

II - Group: zirconium posts - "Nordin" - Switzerland (Fig. 2).

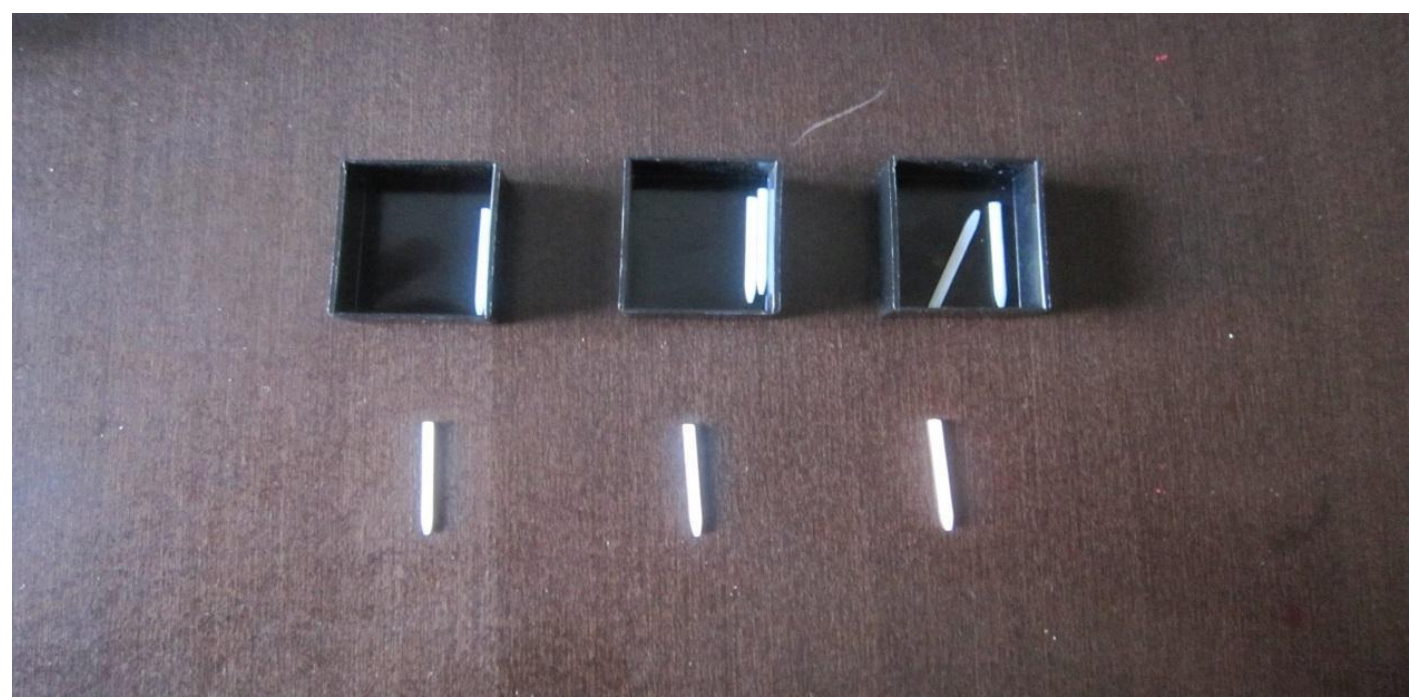

Figure 1-FRC post 


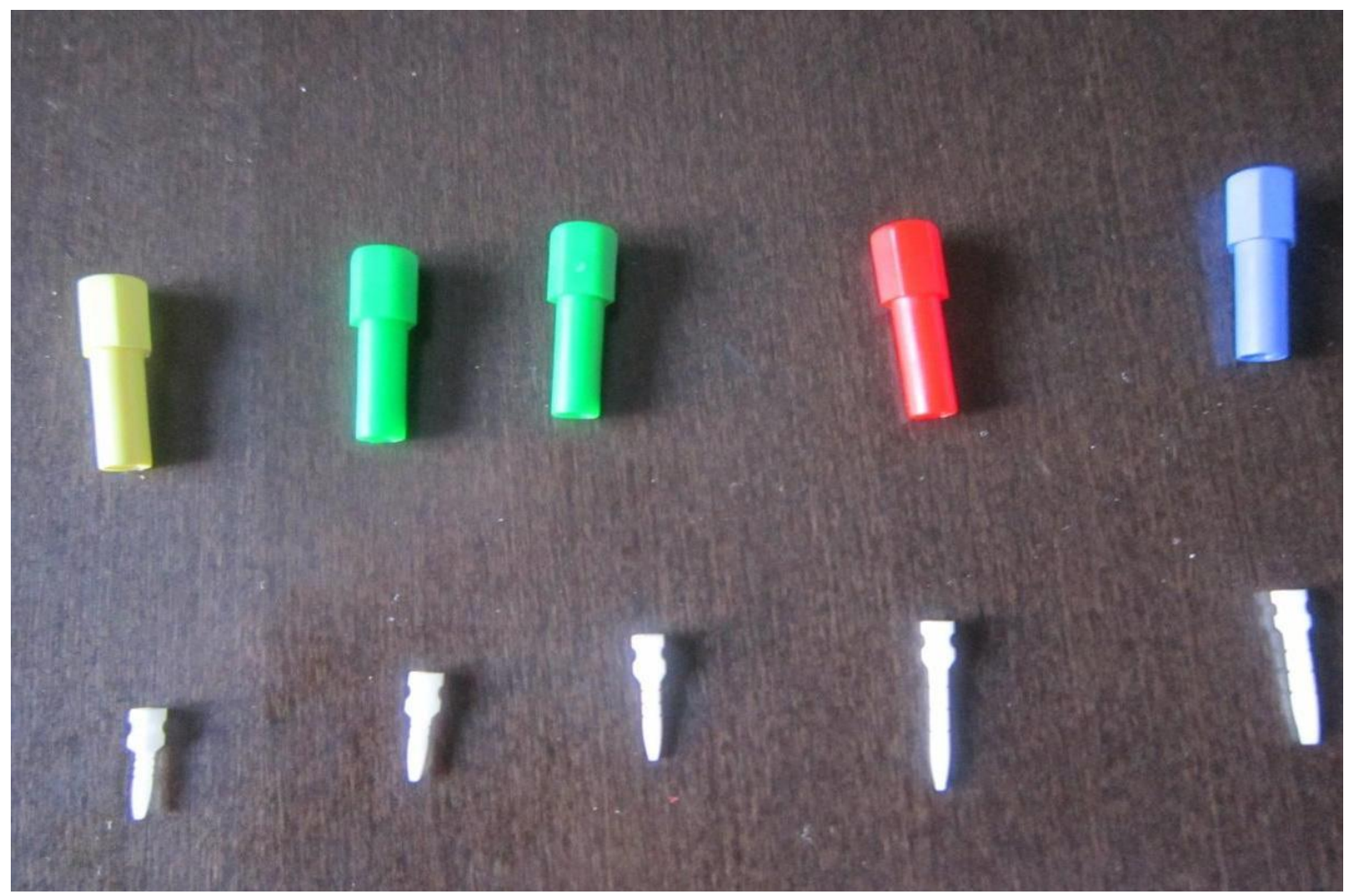

Figure 2-Zirconium posts

In each of the two groups depending on the diameter of the examined posts, three subgroups of posts selected by diameter were formed. A total of 60 posts were investigated.

All examined posts were factory ready posts from which the FRC posts and the zirconnium posts were with smooth surface.

The examined posts were placed in a water bath for two weeks and afterwards they were prepared for experimental examination. For the examination we used specially prepared surface, which was used for the placement of the posts. The examinations were performed at the Faculty of Mechanical Engineering using the universal testing machine "Shimadzu Universal Testing Machine" (Fig. 3). The posts were placed at same distance and on each of them the force was applied at the same place. The speed of movement of the post was 0.5 $\mathrm{mm} / \mathrm{min}$. The force of fracture was recorded in a special software system connected to the machine "Shimadzu". For the purpose of the investigation we used the so-called "three-point bending test" - bending force examination.

The three-point method for load application on the factory ready FRC and zirconium posts involves bending test on three places. According to the ISO 10477 standard the three point method was used for force application until fracture to determine the fracture and bending force, as well as the force module during bending on the examined posts. All posts were tested at room temperature of $22^{\circ}$ Celsius.

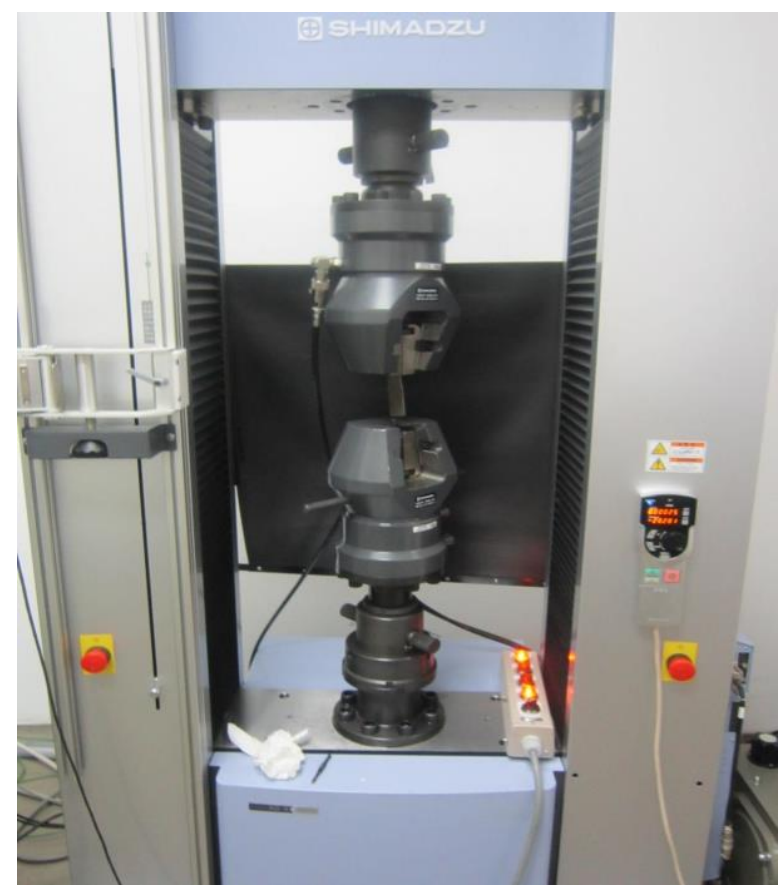

Figure 3 - Shimadzu universal Testing Mashine

The bending strength $(\delta f)$ and the modulus of the bending strength (EF) were calcula- 
ted according to the formula (Torbjörner et al 1996)

Formula 1: $\delta \mathbf{f}=\mathbf{8}$ Fmax $\mathbf{l} / \pi \mathrm{d}^{3}$

Formula 2: $\quad \mathbf{E f}=\mathbf{S} 4 \mathbf{l}^{\mathbf{3}} /\left(\mathbf{3} \boldsymbol{\pi} \mathbf{d}^{\mathbf{3}}\right)$ where the maximal force Fmax is the applied load (N) in the highest point of the curvature of load deviation, 1 is the length, $\mathrm{d}$ is the diameter of the samples. $\mathrm{S}=\mathrm{F} / \mathrm{D}$, stiffness $(\mathrm{N} / \mathrm{m})$ and $\mathrm{D}$ which represents the deviation corresponding to the load $\mathrm{F}$ in the point of the straight line.

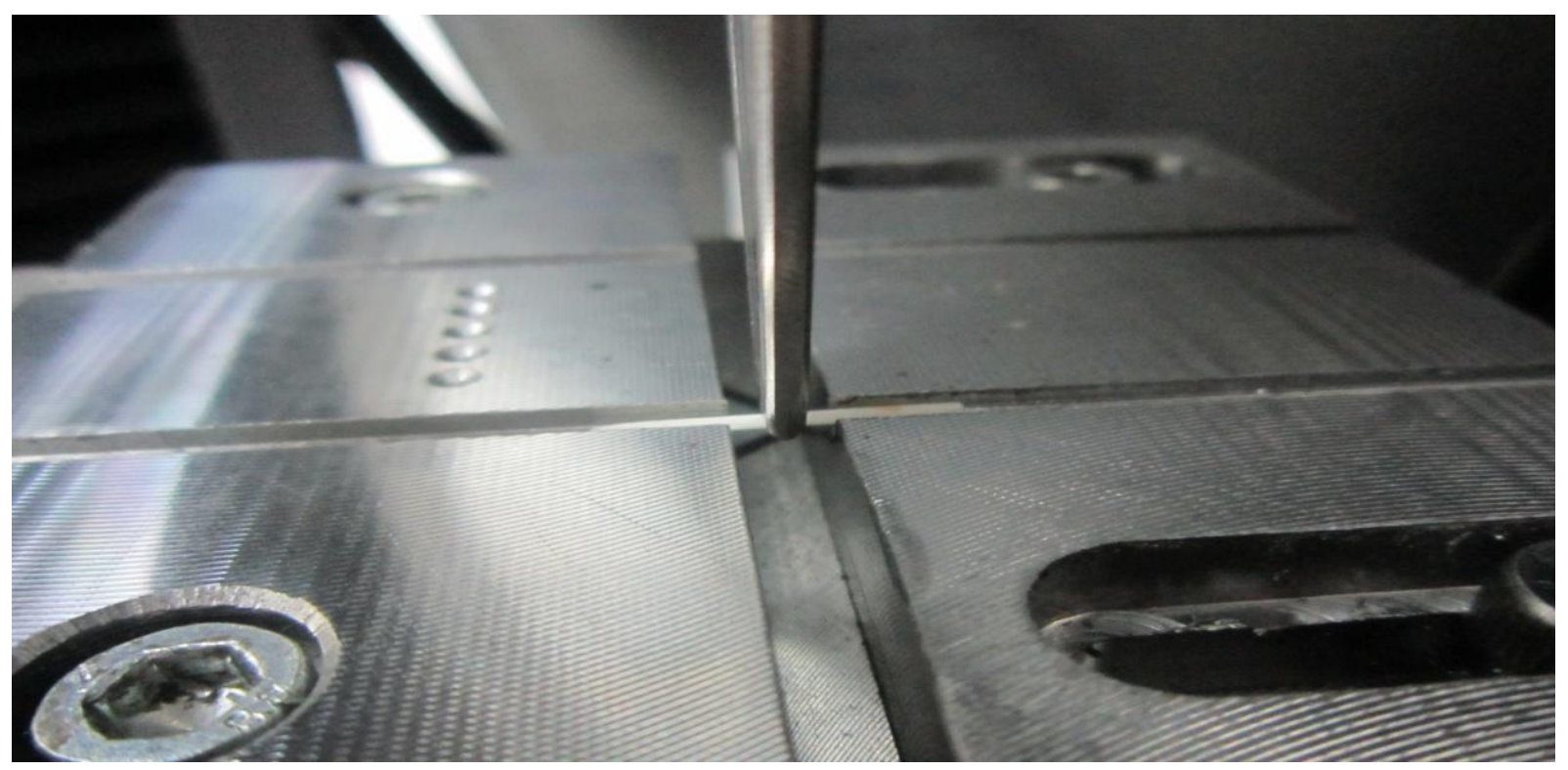

Three point bending test on FRC post

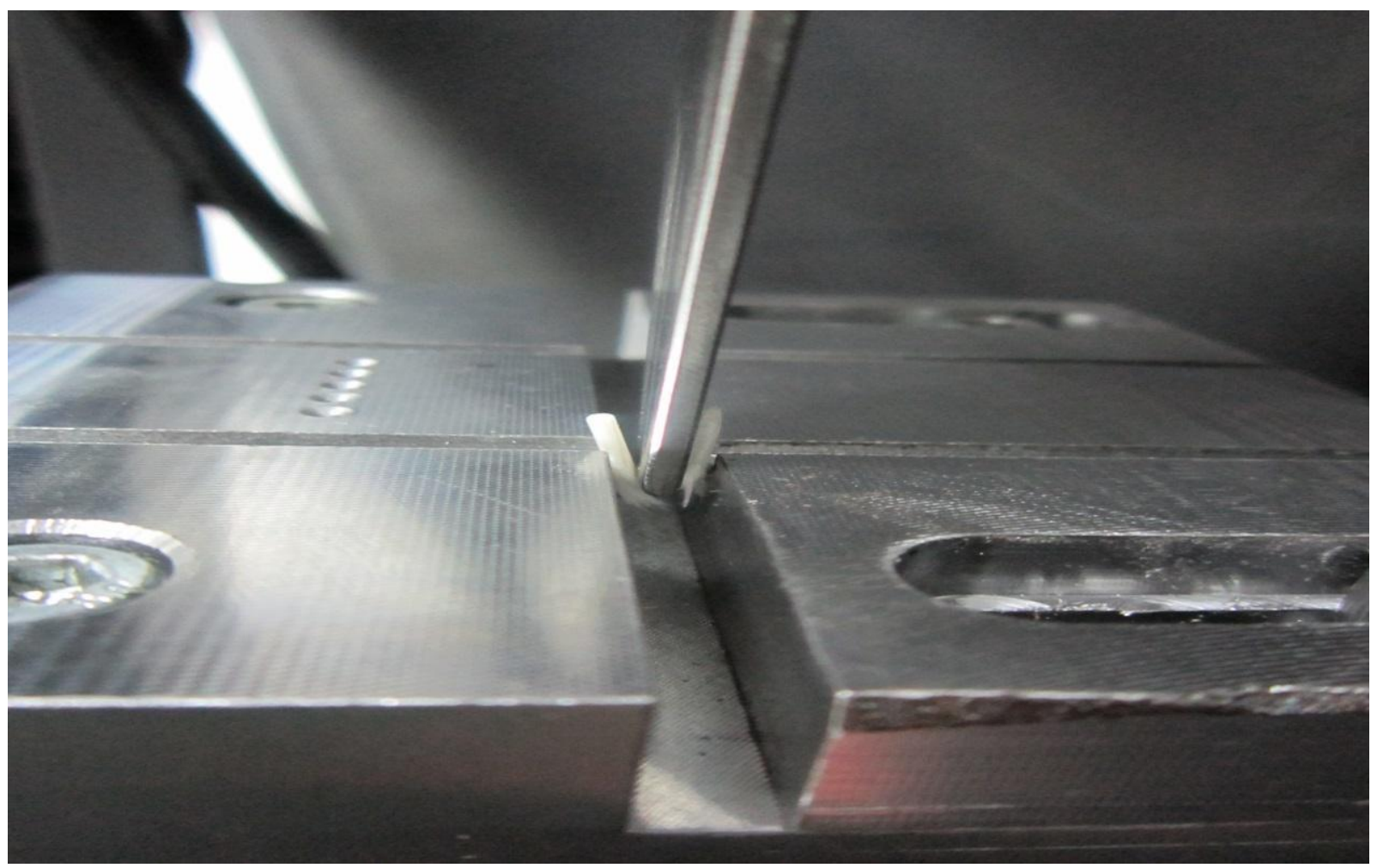

Three point bending test on zirkonium post

\section{Results}

The main values for the fracture force measured on the FRC posts with different diameters on the patients from the first group are presented in Table 1a. The fracture force measured on the FRC posts in subgroup 1 is $45.37900 \mathrm{~N}$, in subgroup 2 is $71.56500 \mathrm{~N}$ and in subgroup 3 is $73.67090 \mathrm{~N}$. 
The main values for the fracture force measured on zirconium posts with different diameters on the patients from the second group are presented in Table $1 \mathrm{~b}$. The fracture force measured on the FRC posts in subgroup 1 is $34.80900 \mathrm{~N}$ in subgroup 2 is $46.53100 \mathrm{~N}$ and in subgroup 3 is $67.15390 \mathrm{~N}$.

Table 1a

Fracture force measured on FRC posts for Group 1 patients

\begin{tabular}{|c|c|c|c|c|}
\hline \multicolumn{5}{|c|}{ Fracture force measured on FRC posts for Group 1 patients } \\
\hline Subgroups & $\begin{array}{l}\text { Subgroup I } \\
D=1.2 \mathrm{~mm}\end{array}$ & $\begin{array}{l}\text { Subgroup II } \\
D=1.35 \mathrm{~mm}\end{array}$ & $\begin{array}{c}\text { Subgroup III } \\
D=1.5 \mathrm{~mm} \\
\end{array}$ & Total \\
\hline Means & $45.37900 \mathrm{~N}$ & $71.56500 \mathrm{~N}$ & $73.67090 \mathrm{~N}$ & $63.53830 \mathrm{~N}$ \\
\hline Std.Dev. & 0.00510 & 0.00560 & 0.00458 & 13.08932 \\
\hline Std.Err. & 0.001612 & 0.001770 & 0.001449 & 2.389772 \\
\hline Minimum & 45.36900 & 71.55400 & 73.66300 & 45.36900 \\
\hline Maximum & 45.38700 & 71.57500 & 73.67900 & 73.67900 \\
\hline Median & 45.37900 & 71.56500 & 73.67100 & 71.56500 \\
\hline Confidence-95\% & 45.37535 & 71.56100 & 73.66762 & 58.65067 \\
\hline Confidence $+95 \%$ & 45.38265 & 71.56900 & 73.67418 & 68.42593 \\
\hline
\end{tabular}

Table 1b

Fracture force measured on zirconium posts for Group 2 patients

\begin{tabular}{|c|c|c|c|c|}
\hline \multicolumn{5}{|c|}{ Fracture force measured on zirconium posts for Group 2 patients } \\
\hline Subgroups & $\begin{array}{l}\text { Subgroup I } \\
\mathrm{D}=1.2 \mathrm{~mm}\end{array}$ & $\begin{array}{l}\text { Subgroup II } \\
\text { D= } 1.35 \mathrm{~mm}\end{array}$ & $\begin{array}{c}\text { Subgroup III } \\
\mathrm{D}=1.5 \mathrm{~mm} \\
\end{array}$ & Total \\
\hline Means & $34.80900 \mathrm{~N}$ & $46.53100 \mathrm{~N}$ & $67.15390 \mathrm{~N}$ & 49.49797 N \\
\hline Std.Dev. & 0.00624 & 0.00435 & 0.00441 & 13.59894 \\
\hline Std.Err. & 0.001972 & 0.001374 & 0.001394 & 2.482816 \\
\hline Minimum & 34.79800 & 46.52200 & 67.14700 & 34.79800 \\
\hline Maximum & 34.82100 & 46.53900 & 67.16100 & 67.16100 \\
\hline Median & 34.80900 & 46.53100 & 67.15400 & 46.53100 \\
\hline Confidence $-95 \%$ & 34.80454 & 46.52789 & 67.15075 & 44.42004 \\
\hline Confidence $+95 \%$ & 34.81346 & 46.53411 & 67.15705 & 54.57590 \\
\hline
\end{tabular}

The main values for the bending strength measured on FRC posts with different diameters on the patients from the first group are presented in Table 2a. The bending strength measured on the FRC posts in subgroup 1 is
$401.4420 \mathrm{~N}$, in subgroup 2 is $444.6425 \mathrm{~N}$ and in subgroup 3 is $333.6828 \mathrm{~N}$.

The main values for the bending strength measured on zirconium posts with different diameters on the patients from the second group 
are presented in Table $2 \mathrm{~b}$. The bending strength measured on zirconium posts in subgroup 1 is
$307.9352 \mathrm{~N}$, in subgroup $2 \mathrm{~N}$ is $289.1030 \mathrm{~N}$ and in subgroup 3 is $304.1649 \mathrm{~N}$.

Table $2 \mathrm{a}$

Bending strength measured on FRC posts for Group 1 patients

\begin{tabular}{|l|c|c|c|c|}
\hline \multicolumn{5}{|l|}{ Bending strength measured on FRC posts for Group 1 patients } \\
\hline Subgroups & $\begin{array}{c}\text { Subgroup I } \\
\mathrm{D}=1.2 \mathrm{~mm}\end{array}$ & $\begin{array}{c}\text { Subgroup II } \\
\mathrm{D}=1.35 \mathrm{~mm}\end{array}$ & $\begin{array}{c}\text { Subgroup III } \\
\mathrm{D}=1.5 \mathrm{~mm}\end{array}$ & Total \\
\hline Means & $\mathbf{4 0 1 . 4 4 2 0 \mathrm { N }}$ & $\mathbf{4 4 4 . 6 4 2 5} \mathrm{N}$ & $\mathbf{3 3 3 . 6 8 2 8} \mathrm{N}$ & $393.2557 \mathrm{~N}$ \\
\hline Std.Dev. & $\mathbf{0 . 0 4 5 1 1}$ & $\mathbf{0 . 0 3 4 7 8}$ & $\mathbf{0 . 0 2 0 7 5}$ & 46.44817 \\
\hline Std.Err. & $\mathbf{0 . 0 1 4 2 6 4}$ & $\mathbf{0 . 0 1 0 9 9 8}$ & $\mathbf{0 . 0 0 6 5 6 2}$ & $\mathbf{8 . 4 8 0 2 3 6}$ \\
\hline Minimum & $\mathbf{4 0 1 . 3 5 3 5}$ & $\mathbf{4 4 4 . 5 7 4 1}$ & $\mathbf{3 3 3 . 6 4 7 0}$ & $\mathbf{3 3 3 . 6 4 7 0}$ \\
\hline Maximum & $\mathbf{4 0 1 . 5 1 2 7}$ & $\mathbf{4 4 4 . 7 0 4 6}$ & $\mathbf{3 3 3 . 7 1 9 5}$ & $\mathbf{4 4 4 . 7 0 4 6}$ \\
\hline Median & $\mathbf{4 0 1 . 4 4 2 0}$ & $\mathbf{4 4 4 . 6 4 2 5}$ & $\mathbf{3 3 3 . 6 8 3 2}$ & 401.4420 \\
\hline Confidence - 95\% & $\mathbf{4 0 1 . 4 0 9 7}$ & $\mathbf{4 4 4 . 6 1 7 6}$ & $\mathbf{3 3 3 . 6 6 7 9}$ & 375.9117 \\
\hline Confidence + 95\% & $\mathbf{4 0 1 . 4 7 4 2}$ & $\mathbf{4 4 4 . 6 6 7 4}$ & $\mathbf{3 3 3 . 6 9 7 6}$ & 410.5998 \\
\hline
\end{tabular}

Table $2 b$

Bending strength measured on zirconium posts for Group 2 patients

\begin{tabular}{|l|l|l|l|l|}
\hline \multicolumn{5}{|c|}{ Bending strength measured on zirconium posts for Group 2 patients } \\
\hline Subgroups & $\begin{array}{l}\text { Subgroup I } \\
\text { D =1.2 mm }\end{array}$ & $\begin{array}{l}\text { Subgroup II } \\
\text { D = 1.35 mm }\end{array}$ & $\begin{array}{l}\text { Subgroup III } \\
\text { D = 1.5 mm }\end{array}$ & Total \\
\hline Means & $\mathbf{3 0 7 . 9 3 5 2 ~ N ~}$ & $\mathbf{2 8 9 . 1 0 3 0 ~ N ~}$ & $\mathbf{3 0 4 . 1 6 4 9 ~ N}$ & $\mathbf{3 0 0 . 4 0 1 1 ~ N ~}$ \\
\hline Std.Dev. & $\mathbf{0 . 0 5 5 1 6 7}$ & $\mathbf{0 . 0 2 7 0 0 3}$ & $\mathbf{0 . 0 1 9 9 6 7}$ & $\mathbf{8 . 2 7 4 9 9 4}$ \\
\hline Std.Err. & $\mathbf{0 . 0 1 7 4 4 5}$ & $\mathbf{0 . 0 0 8 5 3 9}$ & $\mathbf{0 . 0 0 6 3 1 4}$ & 1.510800 \\
\hline Minimum & $\mathbf{3 0 7 . 8 3 7 9}$ & $\mathbf{2 8 9 . 0 4 7 1}$ & $\mathbf{3 0 4 . 1 3 3 6}$ & $\mathbf{2 8 9 . 0 4 7 1}$ \\
\hline Maximum & $\mathbf{3 0 8 . 0 4 1 4}$ & $\mathbf{2 8 9 . 1 5 2 8}$ & $\mathbf{3 0 4 . 1 9 7 0}$ & 308.0414 \\
\hline Median & $\mathbf{3 0 7 . 9 3 5 2}$ & $\mathbf{2 8 9 . 1 0 3 0}$ & $\mathbf{3 0 4 . 1 6 5 3}$ & 304.1653 \\
\hline Confidence - 95\% & $\mathbf{3 0 7 . 8 9 5 8}$ & $\mathbf{2 8 9 . 0 8 3 7}$ & $\mathbf{3 0 4 . 1 5 0 6}$ & $\mathbf{2 9 7 . 3 1 1 1}$ \\
\hline Confidence + 95\% & $\mathbf{3 0 7 . 9 7 4 7}$ & $\mathbf{2 8 9 . 1 2 2 4}$ & $\mathbf{3 0 4 . 1 7 9 2}$ & $\mathbf{3 0 3 . 4 9 1 0}$ \\
\hline
\end{tabular}

The main values for the tensile strength measured on the FRC posts with different diameters on the patients from the first group are presented in Table 3a. The tensile strength measured on the FRC posts in subgroup 1 is $5.442267 \mathrm{~N}$, in subgroup 2 is $4.350545 \mathrm{~N}$ and in subgroup 3 is $2.943465 \mathrm{~N}$.
The main values for the tensile strength measured on zirconium posts with different diameters on the patients from the second group are presented in Table $3 \mathrm{~b}$. The tensile strength measured on the FRC posts in subgroup 1 is $4.224141 \mathrm{~N}$, in subgroup 2 is $3.751466 \mathrm{~N}$, and in subgroup 3 is $3.168756 \mathrm{~N}$. 
Table 3a

Tensile strength measured on FRC posts for Group 1 patients

\begin{tabular}{|l|c|c|c|c|}
\hline \multicolumn{5}{|c|}{ Tensile strength measured on FRC posts for Group 1 patients } \\
\hline Subgroups & $\begin{array}{c}\text { Subgroup I } \\
\text { D = 1.2 mm }\end{array}$ & $\begin{array}{c}\text { Subgroup II } \\
\text { D = 1.35 mm }\end{array}$ & $\begin{array}{c}\text { Subgroup III } \\
\text { D = 1.5 mm }\end{array}$ & Total \\
\hline Means & $\mathbf{5 . 4 4 2 2 6 7 ~ N ~}$ & $4.350545 \mathrm{~N}$ & $\mathbf{2 . 9 4 3 4 6 5} \mathrm{N}$ & $4.245426 \mathrm{~N}$ \\
\hline Std.Dev. & $\mathbf{0 . 0 1 0 5 2 5}$ & $\mathbf{0 . 0 0 5 0 1 9}$ & $\mathbf{0 . 0 0 2 3 8 7}$ & $\mathbf{1 . 0 4 0 3 4 3}$ \\
\hline Std.Err. & $\mathbf{0 . 0 0 3 3 2 8}$ & $\mathbf{0 . 0 0 1 5 8 7}$ & $\mathbf{0 . 0 0 0 7 5 5}$ & $\mathbf{0 . 1 8 9 9 4 0}$ \\
\hline Minimum & $\mathbf{5 . 4 2 4 6 7 5}$ & 4.341971 & $\mathbf{2 . 9 3 9 1 2 0}$ & $\mathbf{2 . 9 3 9 1 2 0}$ \\
\hline Maximum & $\mathbf{5 . 4 6 2 3 7 6}$ & 4.360622 & $\mathbf{2 . 9 4 7 8 2 8}$ & $\mathbf{5 . 4 6 2 3 7 6}$ \\
\hline Median & $\mathbf{5 . 4 4 2 2 4 8}$ & 4.350539 & $\mathbf{2 . 9 4 3 4 6 7}$ & $\mathbf{4 . 3 5 0 5 3 9}$ \\
\hline Confidence - 95\% & $\mathbf{5 . 4 3 4 7 3 8}$ & 4.346954 & $\mathbf{2 . 9 4 1 7 5 8}$ & $\mathbf{3 . 8 5 6 9 5 5}$ \\
\hline Confidence + 95\% & $\mathbf{5 . 4 4 9 7 9 7 ~ N}$ & $4.354135 \mathrm{~N}$ & $\mathbf{2 . 9 4 5 1 7 3}$ & $\mathbf{4 . 6 3 3 8 9 6}$ \\
\hline
\end{tabular}

Table $3 b$

Tensile strength measured on zirconium posts for Group 2 patients

\begin{tabular}{|l|c|c|c|c|}
\hline \multicolumn{5}{|c|}{ Tensile strength measured on zirconium posts for Group 2 patients } \\
\hline Subgroups & $\begin{array}{c}\text { Subgroup I } \\
\text { D= 1.2 } \mathbf{~ m m ~}\end{array}$ & $\begin{array}{c}\text { Subgroup II } \\
\text { D= 1.35 } \mathbf{~ m m ~}\end{array}$ & $\begin{array}{c}\text { Subgroup III } \\
\mathbf{D}=\mathbf{1 . 5} \mathbf{~ m m}\end{array}$ & Total \\
\hline Means & $4.224141 \mathrm{~N}$ & $3.751466 \mathrm{~N}$ & $3.168756 \mathrm{~N}$ & $\mathbf{3 . 7 1 4 7 8 8 ~ N}$ \\
\hline Std.Dev. & 0.003962 & 0.002902 & 0.001489 & $\mathbf{0 . 4 3 9 0 2 7}$ \\
\hline Std.Err. & 0.001253 & 0.000918 & 0.000471 & $\mathbf{0 . 0 8 0 1 5 5}$ \\
\hline Minimum & 4.216256 & 3.746289 & 3.166986 & $\mathbf{3 . 1 6 6 9 8 6}$ \\
\hline Maximum & 4.230125 & 3.756657 & 3.171706 & $\mathbf{4 . 2 3 0 1 2 5}$ \\
\hline Median & 4.224141 & 3.751466 & 3.168753 & $\mathbf{3 . 7 5 1 4 6 6}$ \\
\hline Confidence - 95\% & 0.003962 & 3.749390 & 3.167691 & $\mathbf{3 . 5 5 0 8 5 2}$ \\
\hline Confidence +95\% & $\mathbf{0 . 0 0 1 2 5 3}$ & $\mathbf{3 . 7 5 3 5 4 2}$ & $\mathbf{3 . 1 6 9 8 2 2}$ & $\mathbf{3 . 8 7 8 7 2 3}$ \\
\hline
\end{tabular}

\section{Discussion}

\subsection{Fracture force}

Group I is composed of FRC posts which according to the size of the diameter (1.2 $\mathrm{mm}, 1.35 \mathrm{~mm}$ and $1.5 \mathrm{~mm}$ respectively) were divided into three subgroups. For the three subgroups of FRC posts a descriptive analysis of the average fracture strength was made. According to the descriptive analysis of the average fracture force of the three subgroups of titanium posts with different diameter, the FRC posts with $\mathrm{d}=1.5 \mathrm{~mm}$, followed by FRC posts with $\mathrm{d}=$ $1.35 \mathrm{~mm}$ and FRC posts with $\mathrm{d}=1.25 \mathrm{~mm}$ have the highest average maximum fracture force. The analysis of variance - ANOVA, for $p<0.05$ indicates statistically significant difference in the fracture force of the three subgroups of FRC with different diameters. The value of the Spearman's coefficient of correlation between the diameter of the FRC posts and fracture force indicates strong positive connection i.e. with the increase / decrease of the diameter of the post, the fracture force reduces / increases. The second examined group or Group II is composed from zirconium posts which according to the size of the diameter $(1.2 \mathrm{~mm}, 1.35 \mathrm{~mm}$ and $1.5 \mathrm{~mm}$ correspondingly) were divided into three subgroups. The average fracture force was analyzed for the three subgroups of zirconnium posts. According to the descriptive analysis of 
the average fracture force of the three subgroups with different post diameter, the highest average maximum fracture force had the zirconium posts with $\mathrm{d}=1.5 \mathrm{~mm}$, followed by zirconium posts with $\mathrm{d}=1.35 \mathrm{~mm}$ and zirconium posts with $\mathrm{d}=1.25 \mathrm{~mm}$. The comparison of the average fracture force between the three subgroups of zirconium posts with different diameter indicates that the average fracture force was highest in the subgroup III which also had the longest post diameter and was lowest in the subgroup I which had the shortest post diameter.

The analysis of variance - ANOVA, for $\mathrm{p}<0.05$ indicates statistically significant difference in the fracture force among the three subgroups of zirconium posts with different diameters. The Spearman's coefficient of correlation between the diameter of the zirconium posts and the fracture force indicates a strong positive correlation i.e. with the increase / decrease of the post diameter, the fracture force is reduced / increased.

This part of the analysis refers to the difference in the fracture force between posts fabricated from different material, but with the same post diameter $(\mathrm{d}=1.2 \mathrm{~mm})$. The descriptive analysis indicates that between the FRC and zirconium posts with the same diameter $(1.2 \mathrm{~mm})$, the FRC posts have the highest average fracture force compared to the zirconium posts. Statistically significant difference between the fracture force in the subgroups with FRC and zirconium posts has been identified with the application of the t-test.

The subgroups with the same diameter $d$ $=1.35$ fabricated from different types of material (FRC and zirconium) were tested in terms of the difference in fracture force. The performed descriptive analysis indicates that between the subgroups of posts with the same diameter $(1.35 \mathrm{~mm})$ the highest average force of fracture have the FRC posts compared to the zirconium posts.

A significant difference between the fracture force in the subgroups with FCR and zirconium posts is identified with the application of the t-test.

The subgroups of the same diameter $\mathrm{d}=$ 1.5 fabricated from different types of materials (fibers and zirconia) were tested in terms of the difference in fracture force. The performed descriptive analysis indicates that between the subgroups of posts with the same diameter (1.5 $\mathrm{mm}$ ) the largest average fracture force have the FRC posts compared to the zirconium posts.

A significant difference between the fracture force in the subgroups with FCR and zirconium posts is identified by the application of the t-test.

\subsection{Bending strength}

The bending strength was measured for the first examined group or Group I composed of FRC posts that according to the size of the diameter $(1.2 \mathrm{~mm}, 1.35 \mathrm{~mm}$ and $1.5 \mathrm{~mm})$ were divided into three subgroups. A descriptive analysis of the bending strength was performed for the three subgroups of FCR posts. According to the descriptive analysis of the bending strength for the three subgroups of FRC posts with different diameter, the maximal average bending strength had the FRC posts with $\mathrm{d}=$ $1.35 \mathrm{~mm}$, followed by FRC posts with $\mathrm{d}=1.2$ $\mathrm{mm}$ and FRC posts with $\mathrm{d}=1.5 \mathrm{~mm}$. The analysis of variance - ANOVA for $\mathrm{p}<0.05$ indicates statistically significant difference in the bending strength between the three subgroups of FRC posts with different diameters. The value of the Spearman's coefficient of correlation between the diameter of the FRC posts and the bending strength indicates a significant negative relationship i.e. reducing the diameter of the post increases the bending strength and the increased diameter of the post reduces the bending strength.

The bending strength was measured on the second examined group or Group II, zirconnium posts that according to the size of the post diameter $(1.2 \mathrm{~mm}, 1.35 \mathrm{~mm}$ and $1.5 \mathrm{~mm})$ were divided into three subgroups. According to the descriptive analysis of the average bending strength of the three subgroups of zirconium posts with different diameter, the maximal average bending strength have the zirconium posts with $\mathrm{d}=1.2 \mathrm{~mm}$, compared with zirconnium posts with $\mathrm{d}=1.5 \mathrm{~mm}$ and the zirconium posts with $\mathrm{d}=1.35 \mathrm{~mm}$.

The analysis of variance - ANOVA, for $\mathrm{p}<0.05$ indicates statistically significant differrence in the strength of bending between the three subgroups of zirconium posts with different diameters. The value of the Spearman's coefficient of correlation between the diameter of the zirconium posts and the bending strength, in- 
dicates a significant negative correlation i.e. with the increase / decrease of the diameter of the posts, the bending strength increases / decreases.

As part of the research, a comparison to the bending strength between the subgroups of posts that have the same diameter and are fabricated from different materials (FRC and zirconium) has been made.

The analysis indicates that between the FRC and the zirconium posts with the same diameter $(1.2 \mathrm{~mm})$ the highest average bending strength have the FRC posts compared with the zirconium posts. A significant difference between the bending strength in the subgroups with FRC and zirconium posts was identified statistically with the application of the t-test.

A comparison has been made between the bending strength of the posts with $d=1.35$ $\mathrm{mm}$ fabricated from two different types of material (FRC and zirconia) that were tested in relation to the difference of bending strength. The performed analysis suggests that between the subgroups of posts with the same diameter $(1.35 \mathrm{~mm})$ the highest average bending strength have the FRC followed by the zirconium posts.

Statistically significant difference of the bending strength between the subgroups with FRC and zirconium posts was identified with the application of the t-test for two independent samples.

The subgroups of zirconia and FRC posts with the same diameter $\mathrm{d}=1.5 \mathrm{~mm}$, were tested in relation to the difference in the bending strength. The performed descriptive analysis indicates that between the subgroups of posts with the same diameter $(1.5 \mathrm{~mm})$ the highest average bending strength have the FRC posts compared with the zirconium posts.

Significant difference between the bending strength in the subgroups with FRC and zirconium posts is identified with the applying of the t-test for two independent samples.

\subsection{Tensile strength}

In this section of the investigation, the tensile strength was examined in Group I composed of FRC posts which according to the size of the diameter $(1.2 \mathrm{~mm}, 1.35 \mathrm{~mm}$ and $1.5 \mathrm{~mm})$ were divided into three subgroups. In accordance with the descriptive analysis of the tensile strength in the three subgroups with different diameter FRC posts, the highest average tensile strength had the FRC posts with $\mathrm{d}=1.2 \mathrm{~mm}$, in relation to the FRC posts with $\mathrm{d}=1.35 \mathrm{~mm}$ and FRC posts with $d=1.5 \mathrm{~mm}$. The analysis of variance - ANOVA for $p<0.05$ indicates statistically significant difference between the tensile strength in the three subgroups of FRC posts with different diameters. The value of the Spearman's coefficient of correlation between the diameter and the tensile strength of the FRC posts indicates a very significant negative relationship i.e. the increase / decrease of the post diameter increases / decreases the tensile strength.

The average tensile strength was analyzed for the three subgroups of zirconium posts with diameter $1.2 \mathrm{~mm}, 1.35 \mathrm{~mm}$ and $1.5 \mathrm{~mm}$. According to the descriptive analysis of the average tensile strength for the three subgroups of zirconium posts with different diameter, the highest average strength of elasticity had the zirconium posts with $\mathrm{d}=1.2 \mathrm{~mm}$, followed by the zirconium posts with $\mathrm{d}=1.35 \mathrm{~mm}$ and the zirconium posts with $\mathrm{d}=1.5 \mathrm{~mm}$.

The analysis of variance - ANOVA, for $\mathrm{p}<0.05$ indicates a statistically significant difference in the tensile strength between the three subgroups of zirconium posts with different diameters. The value of the Spearman's coefficient of correlation between the diameter of the zirconium posts and the tensile strength indicates a very significant negative correlation i.e. with the increase / decrease of the post diameter, the tensile strength increases / decreases.

In this section a comparison has been made to the strength of elasticity between the subgroups of posts that have same diameter and are fabricated from different materials (FRC and zirconium).

The descriptive analysis indicates that between the subgroups of posts with the same diameter $(1.2 \mathrm{~mm})$, the highest average tensile strength have the FRC posts compared to the zirconium posts.

A comparison of tensile strength of the posts from different material (FRC and zirconia) with $d=1.35 \mathrm{~mm}$ has been made. The performed descriptive analysis indicates that between the subgroups of posts with the same diameter $(1.35 \mathrm{~mm})$ the highest average tensile strength had the FRC posts, compared with the zirconium posts. Statistically significant differ- 
rence between the tensile strength in the subgroups with FRC and zirconium posts was identified by application of the t-test for two independent samples.

The subgroups of zirconia and FRC posts with the same diameter $d=1.5$ were tested in relation to the difference in the tensile strength. The analysis indicates that between the subgroups of posts with the same diameter $(1.5 \mathrm{~mm})$, the highest average tensile strength had the zirconium posts compared with the FRC posts. A statistically significant difference between the tensile strength in the subgroups with FRC and zirconium posts was identified with the application of the t-test for two independent samples.

\section{Conclusion}

Aesthetics, as one of the most important global trends in modern dentistry, encourages the use of the post and core systems that with their good qualities increasingly satisfy the needs of the patients.

1. The different material of the posts with diameter $1.2,1.35$ and $1.5 \mathrm{~mm}$ provides significant differences in the fracture resistance of the post.

2. The diameter of the different types of posts provides different mechanical properties that differently affect the resistance to the fracture force.

3. The longest diameter of the posts significantly increases the resistance to fracture in relation to the two smaller diameters used during the research.

4. The larger diameter, the higher values of the bending strength, as well as the lowest values of the tensile strength of the material contribute to improved mechanical properties of the fiber and zirconium posts.

5. The highest average tensile strength have the FRC posts, followed by the zirconium posts.

In relation to the bending resistance, FRC posts have better values than the zirconium posts.

\section{REFERENCES}

1. Kovacevska G. Stomatoprosthetic rehabilitation of remaining radix with metal post and core restorations as abutments of fixed structures, Skopje, 1995th 2.

2. Jovanovski S., Evaluation of the impact of surface treatment of ceramic post and core restorations and their effect on fracture resistance of endodontically treated teeth, Skopje. 2012, 102-124.
3. Standlee JP, Caputo AA, Hanson EC. Retention of endodontic dowels: effects of cement, dowel length, diameter, and design. J Prosthet Dent. 1978; 39: 400405.

4. Sorensen JA, Engelman MJ. Ferrule design and fracture resistance of endodontically treated teeth. J Prosthet Dent. 1990; 63: 529-536.

5. Rosen H. Operative procedures on mutilated endodontically treated teeth. J Prosthet Dent. 1961; 11: 973-986.

6. Silverstein WH. The reinforcement of weakened pulpless teeth. J. Prosthet Dent. 1964; 14: 372-381.

7. Sorensen JA, Martinoff JT. Intracoronal reinforcement and coronal coverage: a study of endodontically treated teeth. J Prosthet Dent. 1984a; 51: 780-784.

8. Peroz I, Blankenstein F, Lange K-P, Naumann M. Restoring endodontically treated teeth with posts and cores-a review. Quintessence Int. 2005; 36: 737-746.

9. Guzy GE, Nicholls JI. In vitro comparison of intact endodontically treated teeth with and without endopost reinforcement. J Prosthet Dent. 1979; 42:39-44.

10. Trabert KC, Caput AA, Abou-Rass M. Tooth fracture- a comparison of endodontic and restorative treatments. J Endod. 1978; 4: 341-345.

11. Tjan AH, Whang SB. Resistance to root fracture of dowel channels with various thicknesses of buccal dentin walls. J Prosthet Dent. 1985; 53: 496-500.

12. Naumann M, Preuss A, Rosentritt M. Effect of incomplete crown ferrules on load capacity of endodontically treated maxillary incisors restored with fiber posts, composite build-ups, and all-ceramic crowns: an in vitro evaluation after chewing simulation. Acta Odontol Scand. 2006; 64: 31-36.

13. Lang H, Korkmaz Y, Schneider K, Raab WH-M. Impact of endodontic treatments on the rigidity of the root. J Dent Res. 2006; 85: 364-368.

14. Nergiz I, Schmage P, Özcan M, Platzer U. Effect of length and diameter of tapered posts on the retention. J Oral Rehabil. 2002; 29: 28-34.

15. Asmussen E, Peutzfeldt A, Sahafi A. Finite element analysis of stresses in endodontically treated, dowelrestored teeth. J Prosthet Dent. 2005; 94: 321-329.

16. Qualtrough AJE, Chandler NP, Purton DG. A comparison of the retention of tooth-colored posts. Quintessence Int. 2003; 34: 199-201.

17. Cohen BI, Pagnillo M, Musikant BL, Deutsch AS. Comparison of the retentive and photoelastic properties of two prefabricated endodontic post systems. J Oral Rehabil. 1999; 26: 488-494.

18. Shillingburg Jr HT, Fisher DW, Dewhirst RB. Restoration of endodontically treated posterior teeth. J Prosthet Dent. 1970; 24: 401-409.

19. Morgano SM, Milot P. Clinical success of cast metal posts and cores. J Prosthet Dent. 1993; 69: 11-16.

20. Hew YS, Purton DG, Love RM. Evaluation of prefabricated root canal posts. J Oral Rehabil. 2001; 28 : 207-211.

21. Morgano SM, Hashem AF, Fotoohi K, Rose L. A nationwide survey of contemporary philosophies and techniques of restoring endodontically treated teeth. $\mathbf{J}$ Prosthet Dent. 1994; 72: 259-267.

22. Purton DG, Love RM, Chandler NP. Rigidity and retention of ceramic root canal posts. Oper Dent. 2000; 25: 223-227. 
23. Asmussen E, Peutzfeldt A, Heitmann T. Stiffness, elastic limit, and force of newer types of endodontic posts. J Dent. 1999; 27: 275-278.

24. Duret B, Reynaud M, Duret F. A new concept of corono-radicular econstruction: the Composipost (2). Chir Dent Fr. 1990; 60: 69-77.

25. King PA, Setchell DJ. An in vitro evaluation of a prototype CFRC prefabricated post developed for the restoration of pulpless teeth. J Oral Rehabil. 1990; 17: 599-609.

26. Isidor F, Ödman P, Brøndum K. Intermittent loading of teeth restored using prefabricated carbon fiber posts. Int J Prosthodont. 1996; 9: 131-136.

27. Ferrari M, Vichi A, García-Godoy F. Clinical evaluation of fiber-reinforced epoxy resin posts and cast post and cores. Am J Dent. 2000a; 13: 15B-18B.

28. Schmitter M, Rammelsberg P, Gabbert O, Ohlmann B. Influence of clinical baseline findings on the survival of 2 post systems: a randomized clinical trial. Int J Prosthodont. 2007; 20: 173-178.

29. Fokkinga WA, Kreulen CM, Vallittu PK, Creugers NHJ. A structured analysis of in vitro failure loads and failure modes of fiber, metal and ceramic postand-core systems. Int J Prosthodont. 2004; 17: 476-482.

\section{Резиме}

\section{КОМПАРАТИВНА АНАЛИЗА НА МЕХАНИЧКИТЕ ОСОБИНИ НА ФИБЕР И ЦИРКОНИУМСКИ КОЛЧИЫА}

\section{Весна Јуруковска-Шотаровска, Билјана Капушевска}

Стоматолошки факултет, Универзитет „Св Кирил и Методиј“, Скопје, Р. Македонија

Цел: Да се направи компаративна анализа на механички особини на фибер и циркониумски колчиња.
Майеријал и мет̄оg: Пациентите со фибер и циркониум колчиња беа поделени во две групи со по три подгрупи, а секоја од нив се состоеше од 10 испитаници. Подгрупа I со 1,2 мм; подгрупа II со 1.35 мм и подгрупа III со 1,5 мм дијаметарски колчиња. Со помош на Shimadzu Universal Testing Mashine беа мерени сила на фрактура, цврстина на свиткување и еластичност.

Резулйайи: Силата на фрактура за првата група измерена во првата, втората и третата подгрупа беше $34,80900 \mathrm{~N} ; 67,15390 \mathrm{~N} ; 46,53100 \mathrm{~N}$, а за втората група, во првата, втората и третата подгрупа беше 34,80900N; 46,53100N; 67,15390N соодветно. Цврстината на свиткување за првата група измерена во првата, втората и третата подгрупа беше 401,4420N; 444,6425N; 333,6828N, а за втората група, првата, втората и третата подгрупа беше $307,9352 \mathrm{~N} ; 289,1030 \mathrm{~N} ; 304,1649 \mathrm{~N}$ соодветно. Цврстината на еластичност за првата група измерена во првата, втората и третата подгрупа беше $5,442267 \mathrm{~N} ; 4,350545 \mathrm{~N} ; 2,943465 \mathrm{~N}$, а за втората група, првата, втората и третата подгрупа беше 4,224141N; 3,751466N; 3,168756N соодветно.

Заклучоци: Најголемиот дијаметар на колчињата значително ја зголемува отпорноста на фрактура во однос на двата помали дијаметри. Колку е поголем дијаметарот, толку се повисоки вредностите на цврстина на свиткување, а пониски се вредностите на цврстина на еластичност од материјалот, што придонесува за подобрување на механичките својства на фибер и циркониумски колчиња.

Клучни зборови: фибер колчиња, циркониум колчиња, сила на фрактура, цврстина на свиткување, цврстина на еластичност 